\title{
SPEOCOLPODES, A NEW GENUS OF TROGLOBITIC BEETLES FROM GUATEMALA (COLEOPTERA: CARABIDAE)**
}

\author{
By Thomas C. Barr, JR. \\ School of Biological Sciences \\ University of Kentucky \\ Lexington, Kentucky, U. S. A. 40506
}

In early January, 1973, Mr. Henry Frania and Mr. Michael Shawcross visited Seamay Cave, Alta Verapaz, Guatemala, and discovered two specimens of a remarkable troglobitic carabid beetle. "One was collected after dusk running over flowstone near pools of water several hundred yards into the cave. The second was found the next morning, less than 200 yards from the entrance under a rock in a dry, silt-covered flowstone pool, but still well within the dark zone." ( $\mathrm{H}$. Frania, in litt.). Subsequently Mr. Frania referred the specimens to me for study.

The Seamay Cave beetle is of special interest for two reasons:

I) It is the first troglobitic beetle known from Guatemala, and the cave is the farthest south of any troglobitic beetle type locality in North America.

2) The beetle clearly belongs to the Agonini and in body form resembles the species of Rhadine LeConte, but the possession of long setae on the underside of the tarsi and conspicuous lobes on the fourth tarsal segments indicates that its affinities lie not with Rhadine but with the large, heterogeneous group of agonines currently placed in Colpodes M'Leay.

Only one other group of colpodines is known to regularly inhabit caves and to include apparent troglobites, - the various species of Mexisphodrus Barr, from the uplands of central Mexico. These have recently been described by Barr (1965, 1966) and Hendrichs and Bolívar (1966, 1973). Although the sphodrine appearance of some of the first species of Mexisphodrus which came to my attention led me to consider them primitive sphodrines, more recent study of the material now available suggests that they are not true sphodrines at all, but a specialized, rather distinctive-looking line of colpodines. The status of the name Mexisphodrus will depend upon future taxonomic revisions of the colpodines, but I believe it will be useful

*Manuscript received by the editor November 4, 1973. 
at least at the subgeneric level because of the distinctive habitus of its component species.

The Seamay Cave beetle does not appear to be close to Mexisphodrus despite their cavernicolous habitats and despite their inclusion within the colpodines. In Mexisphodrus there are well-formed eyes or eye rudiments, the head is rounded, the pronotum is more or less cordiform with very broadly reflexed sides, the elytral humeri are well developed and prominent, and the color is dark violaceousferruginous. In the Seamay Cave beetle the eye rudiments are minute, the head is twice as long as wide and its sides are subparallel, the pronotum is barrel-shaped, the elytral humeri are completely rounded, and the color is rufotestaceous.

\section{Speocolpodes, new genus}

Slender, elongate, rufotestaceous cave beetles with minute vestiges of eyes and wings; front and middle tarsi with penultimate segment deeply and asymmetrically bilobed; head twice as long as wide, sides subparallel; pronotum widest at middle, hind angles blunt and obtuse.

Integuments generally glabrous; microsculpture on dorsum of head obsolete, obsoletely transverse on pronotal disc, finely and densely transverse on elytra.

Eye rudiment visible only as minute, translucent spot beneath cuticle; labrum with anterior margin broadly convex, 6-setose; two clypeal setae; clypeofrontal groove joining postantennal groove and terminating in lunate depression between anterior and posterior supraorbital punctures. All mouthparts elongate and slender; mandibles falcate, right mandible with large tooth; maxillary palps with terminal segment fusiform, a little shorter than penultimate segment; glossa with apex broadly rounded and bisetose; labial palps bisetose; mentum tooth grooved, truncate; two prebasilar setae each side of submentum behind suture.

Pronotum barrel-shaped, longer than wide, widest at middle, apex slightly narrower than base; two pairs of marginal setae; hind angles obtuse and somewhat rounded, not produced. Metepisterna short, $3 / 4$ as wide as long.

Elytra elongate-elliptical, humeri completely rounded, subapical sinuation absent; scutellar stria very brief, obsolescent; scutellar puncture setiferous; two discal punctures in apical half, on third interval against second stria; umbilicate series $6+2+6$, seventh and eighth punctures rather widely spaced; a single puncture near apex of seventh stria. 
Antenna very long and slender, attaining apical fourth of elytra; pubescence beginning near base of fourth segment. Tarsi with first four segments densely setose beneath, last segment glabrous beneath, claws smooth; fourth segment bilobate, conspicuously so on pro- and mesotarsi, inner lobe longer than outer, fourth metatarsal segment feebly bilobate; two or three basal segments of meso- and metatarsi with feeble lateral ridge.

Male unknown.

Type species: Speocolpodes franiai, new species.

\section{Speocolpodes franiai, new species}

Etymology: Patronymic honoring Mr. Henry Frania, codiscoverer of the species.

Diagnosis: The genus is at present monobasic; the single species is distinguished from all other known species of North American Anchomeninae by the combination of bilobed fourth tarsal segments, vestigial eyes, rufotestaceous color, and slender, elongate body form.

Description: Length 9.5-10.2 mm. Rufotestaceous, shining, polished; integuments generally glabrous except for fixed setae; microsculpture obsolescent on dorsum of head, evanescently transverse on pronotal disc, finely and densely transverse on elytral disc. Body form slender and elongate, appendages all slender and elongate.

Head 2.I times longer than wide (excluding mandibles), sides subparallel, feebly convergent at neck; eye vestigial, represented only by minute rudiment seen as translucent spot through cuticle, about $0.09 \times 0.15 \mathrm{~mm}$. in holotype; labrum 0.4 as long as wide, anterior margin evenly convex; clypeofrontal grooves short, divergent behind level of antennal bases, joining feebly impressed postantennal groove at anterior supraorbital puncture and ending in lunate depression between anterior and posterior supraorbitals; mandibles elongate, slender, falciform, left mandible $1.40 \mathrm{~mm}$. long in holotype; maxillary palps with terminal segment fusiform, about 0.85 as long as penultimate segment, total length of palp (holotype) $1.77 \mathrm{~mm}$., segments in ratio of $1.0: 4.0: 3.6: 3.0$; labial palps with two setae on basal half of penultimate segment (distal seta possibly irregular: short or broken on two of four palps examined, absent on other two palps), total length of palp (holotype) $1.23 \mathrm{~mm}$., segments in ratio of $1: 4: 3$; mentum tooth prominent, grooved, truncate at apex; submentum with two prebasilar setae each side behind suture.

Pronotum I.25 times longer than wide, apex width 0.8 times base width and 0.67 times maximum width, which occurs near middle; 


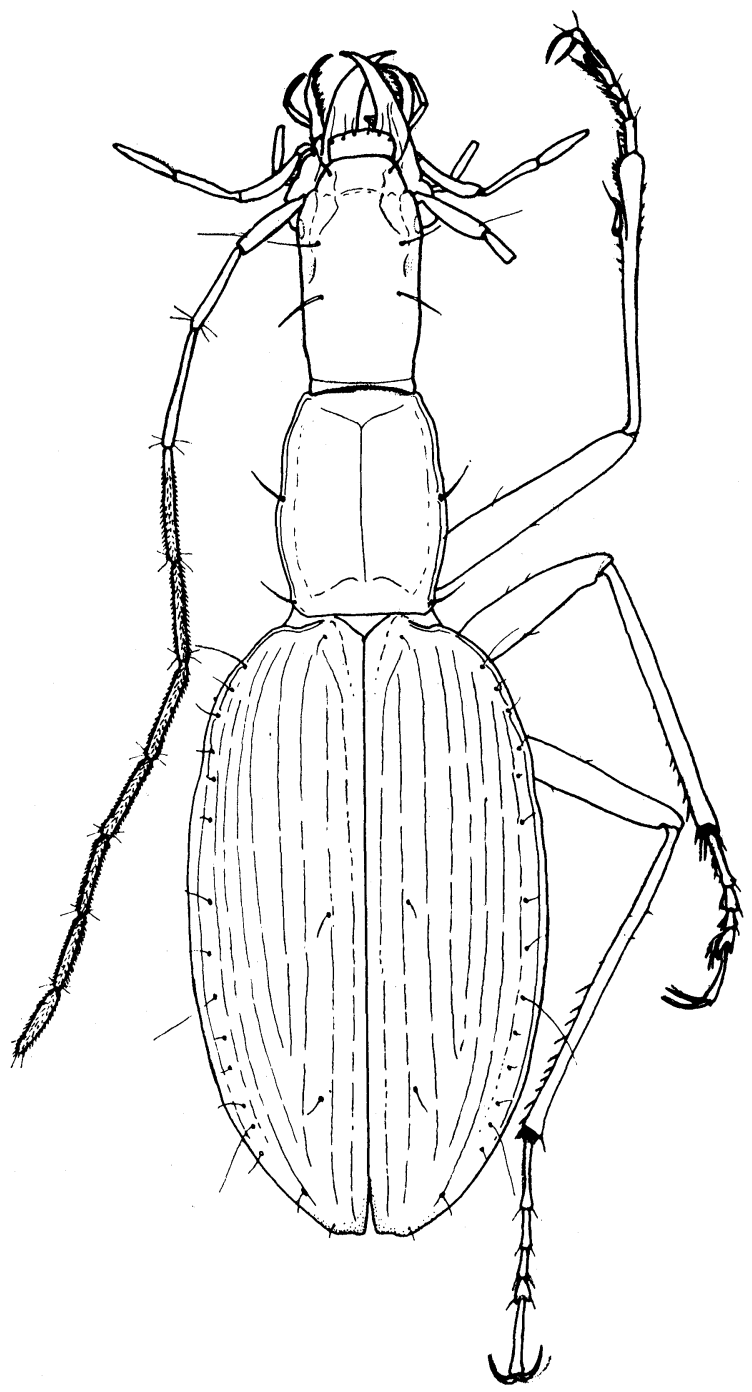

Figure 1. Speocolpodes franiai, new genus and species. Holotype female, length $9.5 \mathrm{~mm}$., Seamay Cave, Alta Verapaz, Guatemala. [Second antennal segment inadvertently omitted on left side of figure; this segment is shown correctly on right side.] 
disc convex, a little deplanate toward sides; anterior angles depressed, sides rounded but shallowly sinuate before middle and before hind angles, which are obtuse, moderately rounded and reflexed; base unmargined; marginal setae placed in margin, anterior pair at middle, posterior pair before hind angles. Prosternum slightly flattened along mid-line; posterior process truncate, but not very sharply so.

Elytra r.8 times longer than wide, humeri completely rounded, sides slightly sinuate in basal fourth, subapical sinuation obsolete; disc convex, striae deep and uninterrupted, intervals convex; scutellar stria very short, obsolescent; first stria either truncating or joining second stria at base, fourth and fifth striae joining in apical fourth and not attaining apex; scutellar puncture setose; two discal punctures on third interval touching second stria, anterior puncture behind middle, posterior puncture in apical fifth; umbilicate series $6+2+6$, spacing between punctures 6 through 9 wide and a little irregular; whips apparently (some broken?) in punctures I, 9, and 13, but not excessively long; seventh stria with a single preapical puncture.

Metathoracic wings vestigial, about $0.7 \mathrm{~mm}$. long (holotype). Abdominal tergites pale, unpigmented, translucent (as in troglobitic Trechinae). Metepisterna short, anterior margin 0.75 as long as lateral margin.

Appendages all slender and elongate. Antenna 0.85 times total body length, first three segments glabrous, pubescence beginning at basal sixth of fourth segment; fourth segment one-third longer than third segment; beginning with scape, segments in length ratio as follows: $1.00: 0.44:$ I.1O : $1.52:$ I.27 : I.22 : I.I4 : 1.10 : I.00 : $0.87: 0.79$ (holotype). Tarsus with fourth segment bilobate, inner lobe longer than outer, lobes prominent on pro- and mesotarsus but inconspicuous on metatarsus; first four segments with long setae beneath, fifth segment glabrous beneath; meso- and metatarsi with feeble ridge on outer side of basal two or three segments; total length of protarsus $1.20 \mathrm{~mm}$. in holotype, segments in length ratio of 1.00 : $0.55: 0.48: 0.29$ (excluding lobes) $: \mathrm{I} .55$.

Male unknown.

Holotype: Female (American Museum of Natural History, New York), Seamay Cave, near Senahú, Alta Verapaz, Guatemala, January 9, 1973, collected by Henry Frania. Approximate elevation 3000 fett; approximate coordinates of type locality as furnished by Mr. Frania, $89^{\circ} 50^{\prime} \times 15^{\circ} 23^{\prime}$.

Paratype: Female, same locality, January 8, 1973, collected by Michael Shawcross. Deposited in T. C. Barr collection, University of Kentucky. 
Measurements of Holotype: total length $9.5 \mathrm{~mm}$., head (excluding mandibles) $2.32 \mathrm{~mm}$. long $\times 1.08 \mathrm{~mm}$. wide, pronotum $1.95 \mathrm{~mm}$. long $\times$ I.55 mm. wide, elytra $5.53 \mathrm{~mm}$. long $\times 2.99 \mathrm{~mm}$. wide, antenna $8.13 \mathrm{~mm}$. long.

\section{Discussion}

Speocolpodes was presumably derived from a colpodine stock with eyes and wings, possibly from a troglophile ancestor which frequented moist, dark microhabitats. Its exact position among the hundreds of species of colpodines inhabiting Mexico and Central America is difficult if not impossible to determine until the taxonomy and phylogeny of the group is better understood.

Seamay Cave, located on the Finca Seamay near Senahú, is one of three caves in which the catopine leiodid beetle Ptomaphagus giaquintoi Jeannel (1949) is known to occur (Peck, 1970). $P$. giaquintoi has small though probably functional eyes and apparently functional metathoracic wings, and is at most a troglophile, even though it shows certain cave adaptations such as long antennae. Although Peck visited Seamay Cave and collected P. giaquintoi there (in June and August), he did not find Speocolpodes in that cave or in nearby Cueva Sepacuite, the largest of three caves on Finca Sepacuite. It is conceivable that the carabids appear seasonally in the cave, and that concentrated search during January or February would yield more specimens.

\section{Literature Cited}

Barr, Thomas C., JR.

1965. A new cavernicolous sphodrine from Veracruz, Mexico (Coleoptera: Carabidae). Coleopterists' Bulletin, 19: 65-72.

1966. New species of Mexisphodrus from Mexican caves (Coleoptera: Carabidae). Psyche, 73: 112-115.

Hendrichs S., Jorge, and C. Bolivar Y Pieltain

1966. Hallazgo de un nuevo Mexisphodrus cavernicola en el Estado de Hidalgo (Mexico): M. gertschi nov. sp. Ciencia, 25: 7-10, pl. 1.

1973. Un nuevo esfodrino ciego del Sotano de San Agustin, Oaxaca, JEANNEL, R. Mexico (Coleopt., Carab.). Ciencia, 28: 37-41.

1936. Monographie des Catopidae. Mem. Mus. Nat. Hist. Nat., n. s., 1: 1-473.

Peck, Stewart B.

1970. A systematic revision and the evolutionary biology of the Ptomaphagus (Adelops) Beetles of North America (Coleoptera: Leiodidae: Catopinae). Harvard University, unpublished doctoral dissertation. 

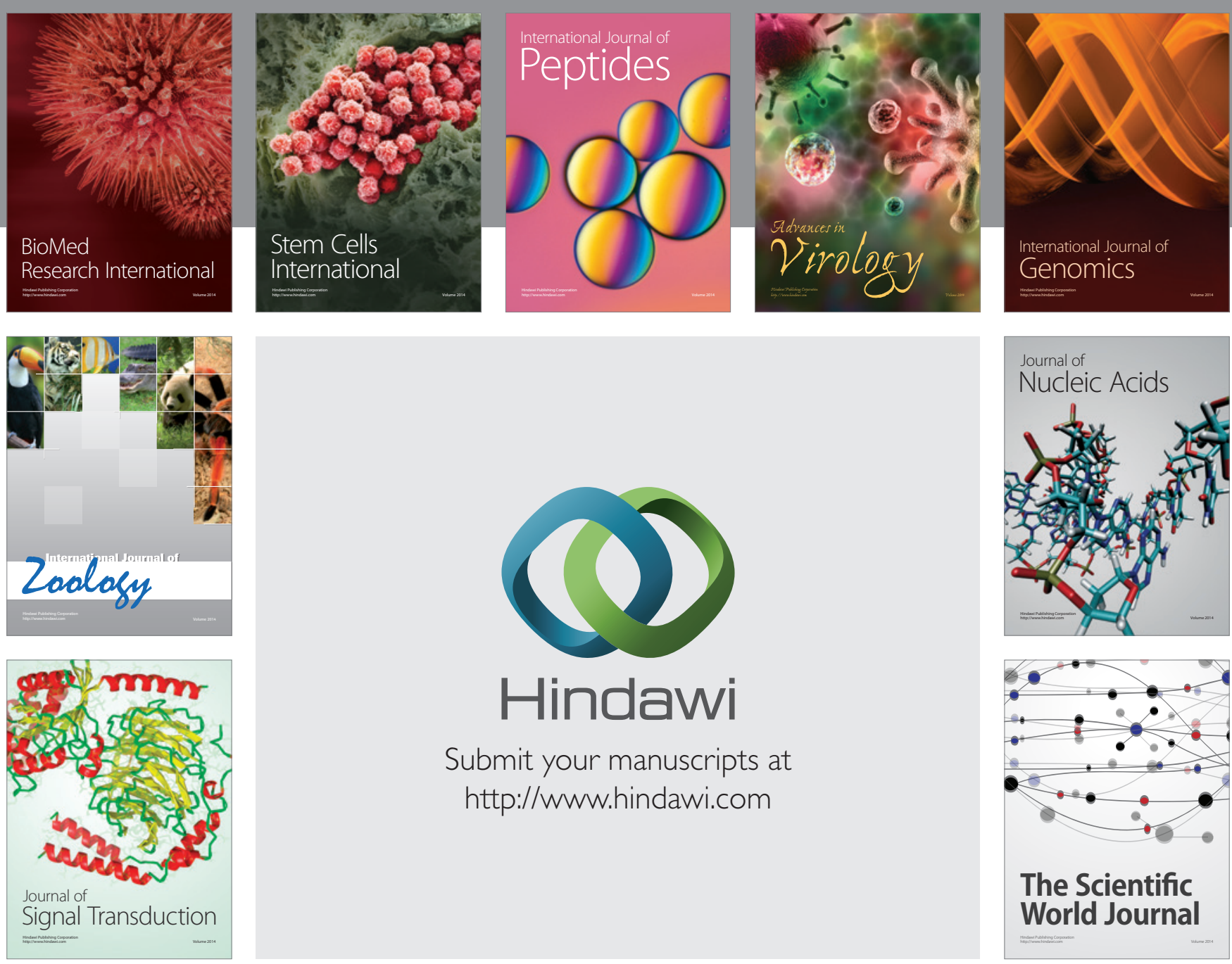

Submit your manuscripts at

http://www.hindawi.com
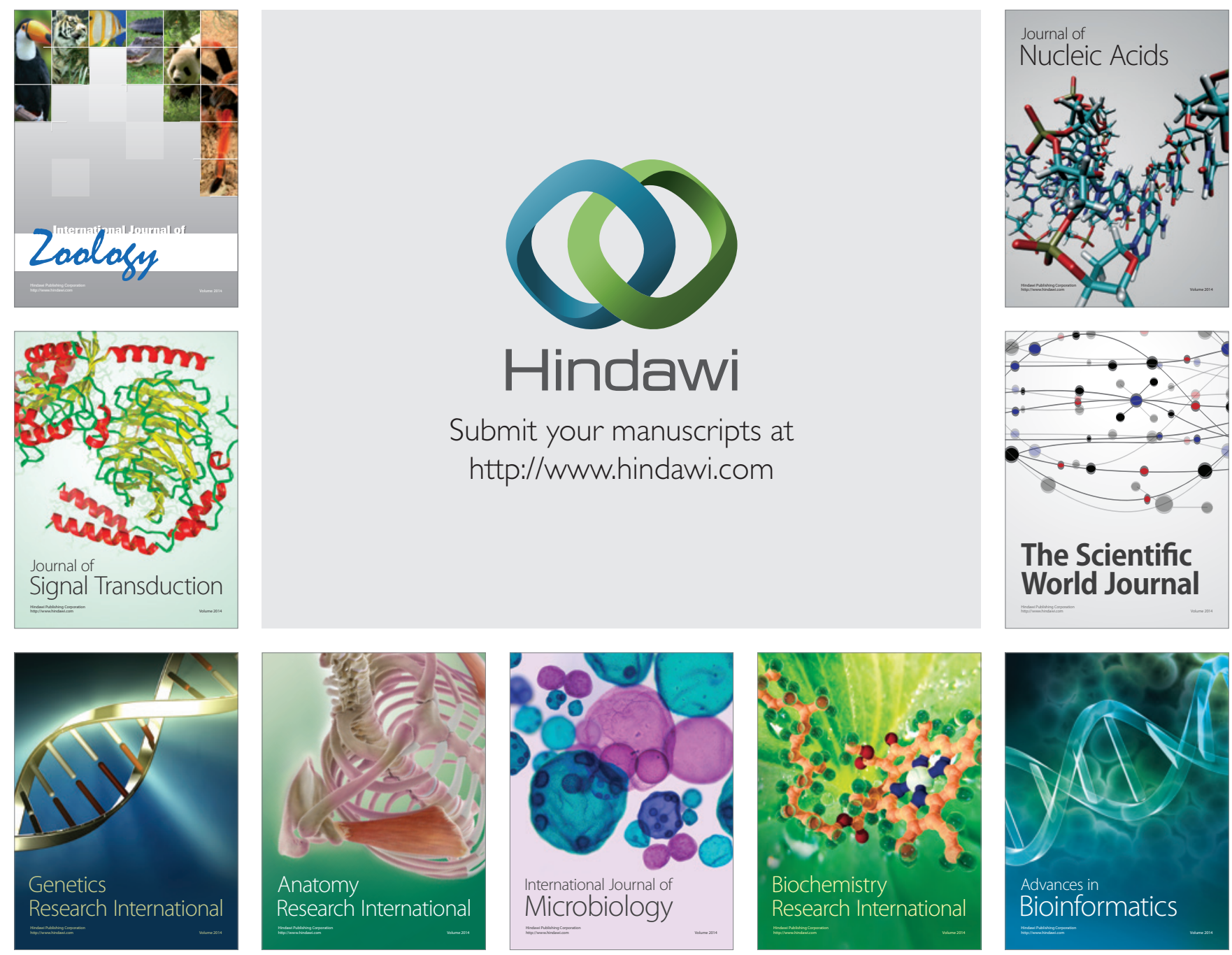

The Scientific World Journal
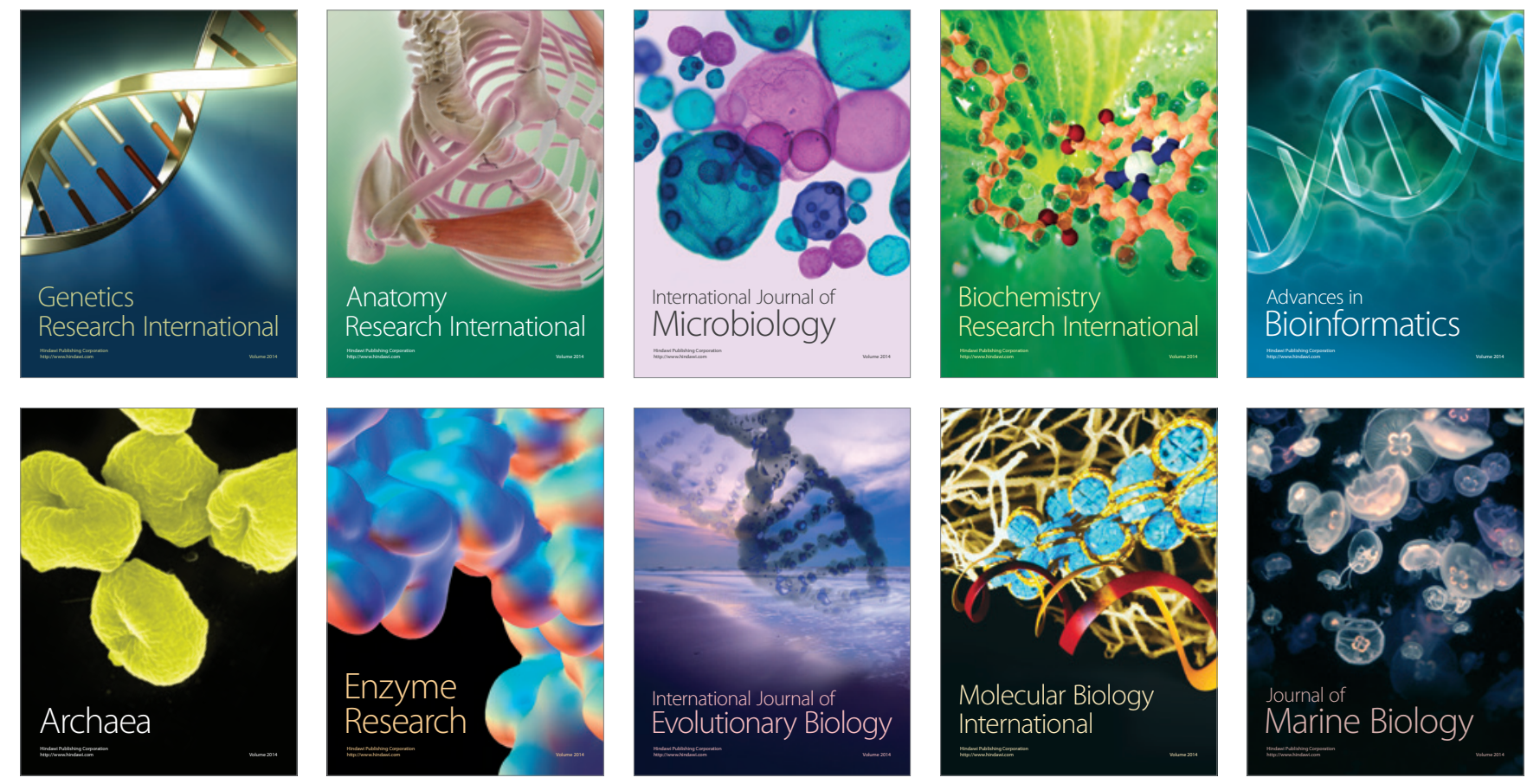